\title{
Adam Wasilewski
}

Instytut Ekonomiki Rolnictwa i Gospodarki Żywnościowej -

Państwowy Instytut Badawczy

e-mail: adam.wasilewski@ierigz.waw.pl

\section{Marek Wigier}

Instytut Ekonomiki Rolnictwa i Gospodarki Żywnościowej -

Państwowy Instytut Badawczy

e-mail: marek.wigier@ierigz.waw.pl

\section{Anna Wasilewska}

Szkoła Główna Gospodarstwa Wiejskiego w Warszawie

e-mail: anna_wasilewska1@sggw.pl

\section{FINANSOWANIE DZIALALNOŚCI BADAWCZO- -ROZWOJOWEJ NA RZECZ WSI I ROLNICTWA W RAMACH HORYZONTU 2020 \\ I WYDATKÓW WEWNĘTRZNYCH}

FUNDING FOR RESEARCH AND DEVELOPMENT

ACTIVITIES TOWARDS THE RURAL AREAS

AND AGRICULTURE IN HORIZON 2020

AND INTERNAL BUDGET EXPENDITURES

DOI: $10.15611 / \mathrm{pn} .2018 .509 .36$

JEL Classification: O38, R51, Q16

Streszczenie: Celem opracowania jest ocena stopnia pozyskiwania środków z programu Horyzont 2020 przez polskie instytucje realizujące projekty związane z rolnictwem i rozwojem obszarów wiejskich oraz ocena wewnętrznego finansowania badań w zakresie nauk rolniczych. Do oceny wykorzystano głównie studia literatury przedmiotu i analizę danych statystycznych obrazujących wartość nakładów na B+R z programu Horyzont 2020 oraz źródeł wewnętrznych. $Z$ analizy dystrybucji środków na badania w zakresie rolnictwa i rozwoju wsi wynika jednak, że zaangażowanie polskich instytucji jest niewielkie. Pozyskiwanie środków z tego źródła jest również uzależnione od ogólnego poziomu wydatków wewnętrznych. Udział wydatków na nauki rolnicze maleje także w odniesieniu do ogólnych wydatków na $\mathrm{B}+\mathrm{R}$. Konsekwencją obecnej skali finansowania działalności $\mathrm{B}+\mathrm{R}$ może być znaczne spowolnienie transferu nowej wiedzy i innowacji do sektora rolno-spożywczego i na obszary wiejskie. 
Słowa kluczowe: transfer wiedzy, sektor badań i rozwoju, źródła finansowania, Horyzont 2020 .

Summary: The aim of the study was to assess the level of obtaining funds from the Horizon 2020 program by Polish institutions implementing projects related to agriculture and rural development, and to assess the internal financing of research in the field of agricultural sciences. In order to carry out this assessment, the literature on the subject was used primarily and the analysis of raising funds for research from the Horizon 2020 program and internal financing of research and development activities was carried out. However, the analysis of distribution of funds for research in the field of agriculture and rural development shows that the involvement of Polish institutions is small. Raising funds from this source is also dependent on the overall level of internal expenditure. The consequence of the current scale of financing $R \&$ D activities may be a significant slowdown in the transfer of new knowledge and innovations to the agri-food sector and rural areas.

Keywords: knowledge transfer, research and development sector, sources of financing, Horizon 2020.

\section{Wstęp}

Jednym z głównych priorytetów zdefiniowanych przez Unię Europejską w strategii rozwoju Europa 2020 jest inteligentny rozwój, który jest w głównej mierze efektem transferu wiedzy i innowacji do różnych sektorów gospodarki. Podobne podejście prezentowane jest przez Komisję Europejską w stosunku do gospodarki żywnościowej i rolnictwa po roku 2020. W dokumencie The Future of Food and Farming... [European Commission 2017b] zakładane jest upowszechnianie badań i innowacji w praktyce gospodarczej oraz na rynkach. Transfer wiedzy i innowacji ma dotyczyć praktycznie wszystkich obszarów prowadzenia działalności gospodarczej, np. uprawy roli, chowu i hodowli zwierząt, zootechniki czy integracji pionowej rolnictwa. Planowana jest również budowa systemu tzw. inteligentnych wsi (smart villages). Zamierzenia te stawiają wyzwania przed sektorem B+R wszystkich krajów Unii Europejskiej. Warunkiem koniecznym sukcesu w ww. obszarach jest ustawiczny rozwój działalności naukowo-badawczej. Wyzwania te dotyczą również polskich instytucji sektora B+R. Inteligentny rozwój wsi i rolnictwa w Polsce wymagać będzie korzystania z zasobów wiedzy powstającej zarówno na poziomie UE, jak i w kraju. Zaangażowanie polskich naukowców w międzynarodowe badania naukowe powinno sprzyjać ich upowszechnianiu i ułatwiać wdrażanie koncepcji rozwoju inteligentnych wsi.

Wiedza jest źródłem postępu społecznego, technologicznego i ekonomicznego. $\mathrm{W}$ procesie transferu innowacji wiedza jest podstawowym nakładem niezbędnym dla jego wytworzenia, ale równocześnie efektem tego procesu. Tworzenie nowych zasobów wiedzy oraz dostosowywanie już istniejących do wymogów praktyki gospodarczej wymaga finansowania działalności $B+R$, które na poziomie Unii zapew- 
nia program Horyzont 2020, a na poziomie poszczególnych państw - ich budżety krajowe. Partycypacja instytucji B+R poszczególnych krajów członkowskich w programie Horyzont 202 oraz wewnętrzne finansowanie ich działalności może w konsekwencji prowadzić do różnicowania tempa inteligentnego rozwoju wsi i rolnictwa. $Z$ tego względu celem opracowania jest ocena stopnia pozyskiwania środków z programu Horyzont 2020 przez polskie instytucje realizujące projekty związane z rolnictwem i rozwojem obszarów wiejskich oraz ocena wewnętrznego finansowania badań w zakresie nauk rolniczych. Do przeprowadzenia tej oceny wykorzystano przede wszystkim studia literatury przedmiotu oraz metody analizy opisowej i porównawczej. Dodatkowo posłużono się analizą korelacji, regresji oraz liniowym modelem trendu. Materiał empiryczny stanowiły dane i informacje o projektach badawczych związanych z rolnictwem i rozwojem obszarów wiejskich, realizowanych z programu Horyzont 2020, które zostały pozyskane z bazy CORDIS, według stanu na 10 października 2017 r. Ponadto w badaniach wykorzystano dane statystyczne Eurostatu.

\section{Podstawy teoretyczne}

W badaniach skoncentrowano się na ocenie poziomu finansowania sektora badawczo-rozwojowego w Polsce. Skala tego finansowania ma bezpośredni wpływ na podnoszenie poziomu wiedzy i umiejętności pracowników oraz poziom innowacyjności gospodarki polskiej, który jest obecnie bardzo niski [European Commission 2017a]. Poprawy innowacyjności wymaga również sektor rolno-spożywczy, którego konkurencyjność wynika głównie z niskich kosztów pracy, a który jednocześnie charakteryzuje się niższą niż w lepiej rozwiniętych państwach UE (np. w Niemczech, Danii czy krajach Beneluksu) wydajnością pracy [Szczepaniak (red.) 2017; Wasilewski 2016]. Kluczem do poprawy konkurencyjności polskiej gospodarki żywnościowej jest efektywniejsze wykorzystanie zasobów, które posiadamy [Wigier (red.) 2014]. Intensyfikacja działalności związanej z poszerzaniem istniejącego zasobu wiedzy, adaptacją istniejących rozwiązań do polskich warunków oraz transferem wiedzy do praktyki gospodarczej staje się koniecznością, jeżeli koncepcja inteligentnego rozwoju wsi ma zostać wdrożona. W literaturze ekonomicznej można znaleźć wiele uzasadnień dla tego twierdzenia. Udowodnione zostało m.in., że kwalifikacje i umiejętności pracowników są czynnikami poprawy produktywności kapitału rzeczowego [Firszt, Jabłoński 2016; Boeke 1953; Hagen 1962; Schultz 1962; McClelland 1962]. Uzyskana w wyniku transferu wiedzy poprawa umiejętności i kwalifikacji determinuje z kolei postęp techniczny [Firszt, Jabłoński 2016; Kondonassis i in. 2000]. Niektórzy autorzy stwierdzają nawet, że kapitał ludzki może mieć w długim okresie silniejszy wpływ na wzrost gospodarczy niż kapitał rzeczowy [Caballe, Santos 1993; Galor, Moav 2004]. Wzrost znaczenia osiągnięć naukowo-badawczych w polskim rolnictwie i uczynienie tego sektora bardziej konkurencyjnym wymaga przede wszystkim zwiększenia nakładów na sferę $\mathrm{B}+\mathrm{R}$ w tym sektorze 
oraz wzrostu aktywności placówek naukowo-badawczych i doradztwa rolniczego w przepływnie tych osiągnięć do praktyki gospodarczej [Dworak i in. 2016].

Endogeniczna teoria wzrostu gospodarczego przyjmuje, że proces tworzenia nowych technologii jest czynnikiem wewnętrznym i wynika z decyzji i aktywności podmiotów w gospodarce [Firszt, Jabłoński 2016]. Jedną z najważniejszych stymulant tego procesu są inwestycje w sferę B+R [Romer 1990; Aghion, Howitt 1992; Aghion, Jarave 2015; Caballero, Jaffe 1993]. Z teorii tej wynika, że tempo tworzenia nowej wiedzy i jej transferu do praktyki gospodarczej zależy od poziomu finansowania tego sektora. Istotną kwestią pozostaje zatem zapewnienie działalności B+R, która obejmuje badania podstawowe, badania stosowane oraz prace rozwojowe, źródeł finansowania umożliwiających odpowiednio dużą skalę inwestycji. W Polsce, w przeciwieństwie do krajów Europy Zachodniej, dominującą rolę w finansowaniu tej działalności odgrywa budżet państwa [Prystrom, Wierzbicka 2015; Wasilewska, Wasilewski 2016]. Z uwagi na niski poziom innowacyjności polskiej gospodarki istnieje natomiast konieczność znacznego zwiększenia nakładów na tę działalność. Przyjmuje się, że coraz większą rolę w tym finansowaniu powinien odgrywać sektor przedsiębiorstw poprzez samofinansowanie czy finansowanie własne zewnętrzne [Prystrom, Wierzbicka 2015]. W sektorze rolnym może być to jednak trudne lub wręcz nierealne. Rozdrobnienie agrarne, uzależnienie produkcji roślinnej od czynników klimatycznych, uzależnienie dochodów gospodarstw rolnych od dopłat bezpośrednich (pomocy publicznej) czy niższe (w porównaniu z działalnością pozarolniczą) dochody ludności wiejskiej mogą poważnie ograniczać możliwości pozabudżetowego finansowania działalności $\mathrm{B}+\mathrm{R}$ w tym sektorze. Spełnienie przez Polskę kryteriów inteligentnego rozwoju wsi i rolnictwa wiązać się będzie zwłaszcza z poziomem finansowania tej działalności przez budżet państwa lub budżet Unii Europejskiej.

Rozważając kwestię finansowania tworzenia i transferu wiedzy i innowacji do praktyki gospodarczej, warto zwrócić uwagę na podejście przedstawicieli Nowej Ekonomii instytucjonalnej do tego problemu. Zdaniem Northa [2005], przytłumiona konkurencja ogranicza motywację organizacji do inwestycji w nową wiedzę i w konsekwencji nie wywołuje nagłych zmian instytucjonalnych. Z kolei silna konkurencja przyspiesza zmiany instytucjonalne. Autor stwierdza ponadto, że przyczyną poprawy efektywności jest głównie konkurencja, a środkiem temu służącym jest podnoszenie poziomu wiedzy. Jeśli konkurencja jest znikoma, to wsparcie rozwoju przedsiębiorczości poprzez subsydiowanie transferu wiedzy może przynieść niewielkie skutki, ponieważ firmy nie będą miały motywacji do jej wykorzystania; odwrotnie będzie w silnie konkurencyjnym środowisku. Z kolei bezpośrednie transfery środków finansowych do wybranych przedsiębiorstw mogą doprowadzić do wyeliminowania konkurencji, a w dłuższej perspektywie ograniczyć skłonności do inwestowania w nową wiedzę ze względu na brak dostatecznej konkurencji. W pewnych warunkach transfery takie mogą mieć jednak korzystne oddziaływanie. Sytuacja taka pojawi się, gdy w warunkach znikomej konkurencji będą się one przyczy- 
niać do powstawania nowych przedsiębiorstw, co zmotywuje istniejące do poprawy efektywności poprzez pozyskiwanie nowej wiedzy.

\section{Finansowanie dzialalności badawczo-rozwojowej}

Zapewnienie działalności $\mathrm{B}+\mathrm{R}$ finansowania jest warunkiem tworzenia $\mathrm{i}$ transferu nowej wiedzy do działalności gospodarczej oraz szeroko rozumianej poprawy innowacyjności. Dotyczy to wszystkich sektorów gospodarki narodowej, w tym sektora rolno-spożywczego. W 2016 r. łączne wydatki wewnętrzne krajów członkowskich Unii Europejskiej na badania i rozwój wyniosły blisko 303 mld euro. W Polsce przeznaczono na ten cel w ok. 4,3 mld euro w 2015 r. i ok. 4,1 mld euro w 2016 (tj. zaledwie ok. 1,4\% łącznych wydatków we wszystkich krajach UE). W 2015 r. tylko na nauki rolnicze w ramach finansowania wewnętrznego wydano blisko $200 \mathrm{mln}$ euro, co stanowiło ok. 4,5\% ogólnych wydatków na B+R.

Od wstąpienia Polski do UE ważnym źródłem transferu wiedzy dla sektora rolno-spożywczego i szeroko rozumianej gospodarki wiejskiej mogą być wyniki badań międzynarodowych zespołów badawczych, finansowanych ze wspólnego budżetu. Uczestnictwo polskich instytucji naukowo-badawczych w programach unijnych przekłada się bezpośrednio na transfer wiedzy i usług o charakterze naukowo-badawczym do praktyki gospodarczej. W UE od 2014 r. realizowany jest program Horyzont 2020. Dotychczas w ramach tego programu 194 projekty dotyczyły rozwoju rolnictwa i obszarów wiejskich. Łącznie w badaniach tych uczestniczyło 1637 instytucji naukowo-nadawczych, w tym 1398 z krajów UE. Łączny budżet tych projektów przekroczył 402,8 mln euro, z czego 369,5 mln euro stanowił wkład z budżet instytucji z krajów UE.

$\mathrm{Z}$ analiz wynika, że zaangażowanie polskich instytucji w badania na rzecz rozwoju rolnictwa i obszarów wiejskich, w tym poprawy innowacyjności gospodarki wiejskiej, jest niewielkie - uczestniczy w nich jedynie 30 instytucji, czyli ok. 1,8\% wszystkich. Łączny ich budżet wynosi ok. 4,3 mln euro, co stanowi 1,1\% ogólnego budżetu projektów związanych z rozwojem rolnictwa i obszarów wiejskich oraz 1,2\% budżetu instytucji krajów członkowskich UE (rys. 1). Pod względem środków pozyskiwanych na powyższe cele z programu Horyzont 2020 Polska jest dopiero na 14. pozycji wśród krajów UE.

Skala transferu środków finansowych z programu Horyzont 2020 jest w pewnym stopniu odzwierciedleniem skali ogólnych wydatków wewnętrznych na $\mathrm{B}+\mathrm{R}$. Najwięcej środków finansowych z tego programu pozyskują instytucje z krajów ponoszących znacznie wyższe wydatki wewnętrzne na finansowanie sektora $\mathrm{B}+\mathrm{R}$ (rys. 1). W Polsce udział wydatków wewnętrznych w wydatkach krajów członkowskich UE na B+R wynosi niespełna 1,4\%. Udział środków pozyskiwanych przez polskie instytucje naukowo-badawcze w budżecie projektów związanych z rozwojem rolnictwa i obszarów wiejskich jest na poziomie zbliżonym do udziału Polski w ogólnej kwocie wydatków wewnętrznych krajów UE na działalność B+R. 


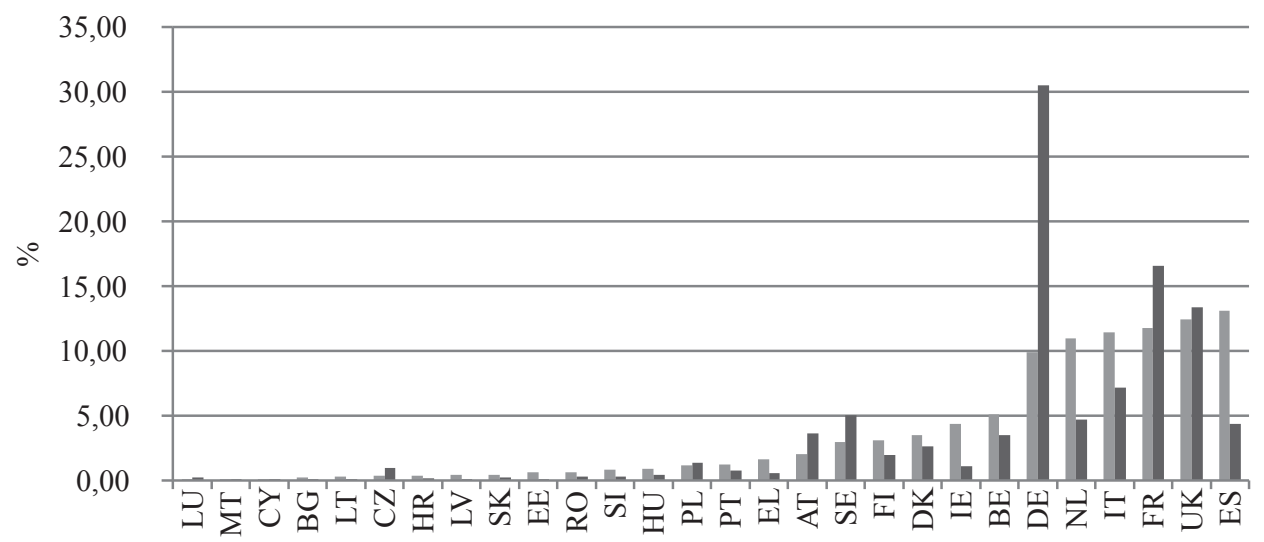

- Udział krajów członkowskich w ogólnej kwocie projektów H2020 związanych z rolnictwem lub rozwojem obszarów wiejskich

- Udział krajów członkowskich w ogólnej kwocie wydatków wewnętrznych na badania i rozwój w 2016 r.

Rys. 1. Wydatki wewnętrzne na badania i rozwój i pozyskiwanie środków finansowych z programu Horyzont 2020 na badania związane z rolnictwem lub rozwojem obszarów wiejskich w krajach Unii Europejskiej

Źródło: obliczenia własne na podstawie danych CORDIS oraz EUROSTAT.

Analizując dystrybucję środków programu Horyzont 2020 pomiędzy kraje Unii Europejskiej oraz skalę ich wydatków wewnętrznych B+R (rys. 1), trzeba zwrócić uwagę na jeszcze jedną kwestię. W grupie największych beneficjentów programu można wyodrębnić dwa typy krajów. Przykładem pierwszego są Niemcy i Francja: względny poziom wydatków na badania i rozwój znacznie przekracza względny poziom pozyskiwanych środków z programu Horyzont 2020 na projekty związane z rolnictwem i rozwojem obszarów wiejskich. Można w związku z tym przyjąć, że kraje te większą wagę przywiązują do finansowania wewnętrznego. Niemniej efektem jest również względnie duża skala pozyskiwanych środków unijnych. Do typu drugiego należy zaliczy przede wszystkim Hiszpanię, Włochy i Holandię - tu występuje sytuacja odwrotna: znacznie wyższy jest względny poziom pozyskiwanych środków unijnych, co oznacza, że kraje te znacznie lepiej wykorzystują szansę, jaką jest finansowanie badań ze źródeł międzynarodowych, posiadają odpowiednio przygotowane do tego zaplecze naukowe i administracyjne, a oferty badawcze składane w trybie konkursowym są atrakcyjne i konkurencyjne. 


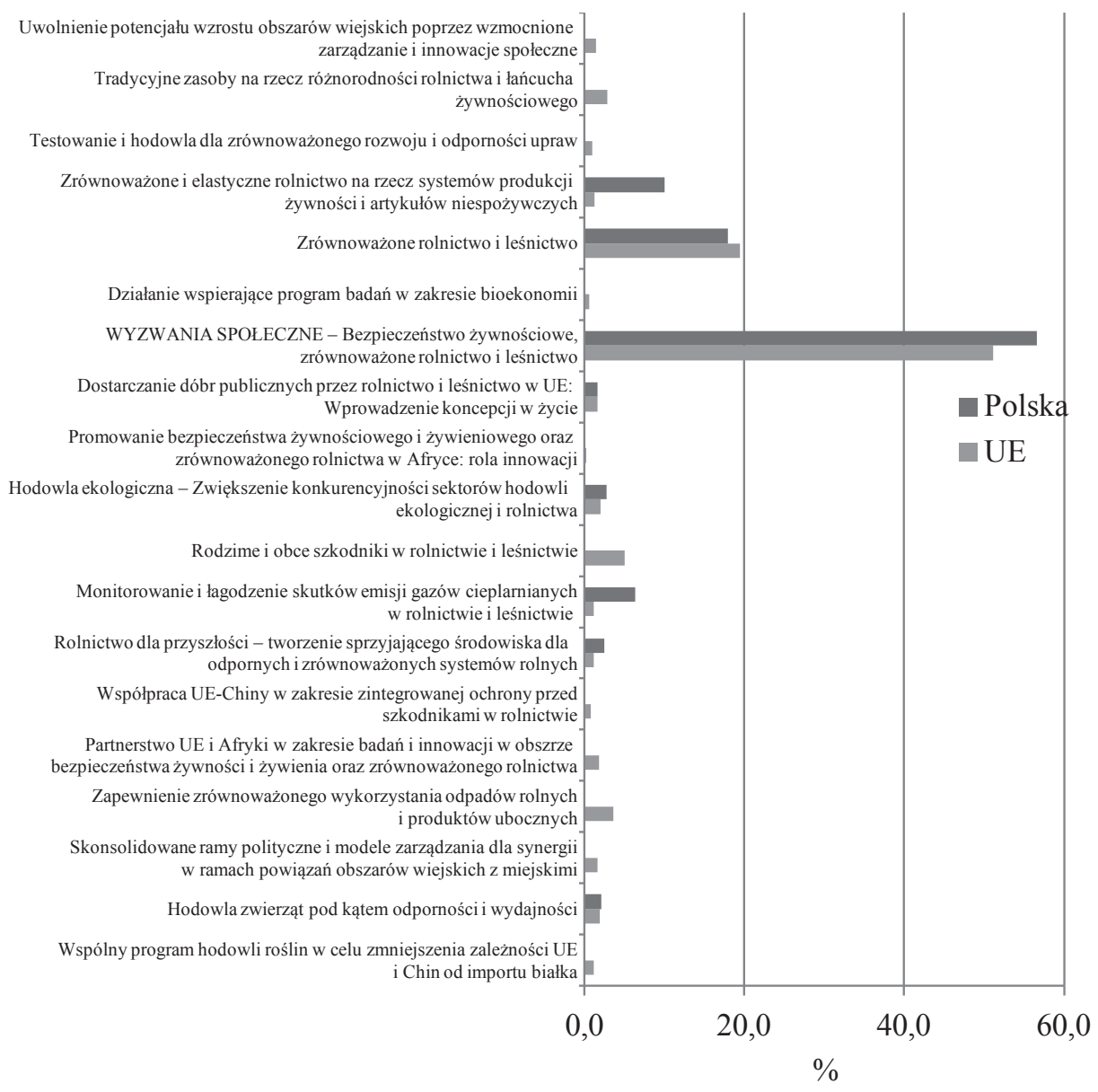

Rys. 2. Udział poszczególnych kierunków badań w ogólnej kwocie środków programu Horyzont 2020, zakontraktowanej w ramach projektów związanych z rolnictwem i rozwojem obszarów wiejskich

Źródło: opracowanie własne na podstawie danych CORDIS.

Występowanie istotnej zależności pomiędzy poziomem wydatków wewnętrznych na $\mathrm{B}+\mathrm{R}$ a poziomem środków pozyskiwanych z programu Horyzont 2020 na badania związane z rozwojem rolnictwa i obszarów wiejskich potwierdza przeprowadzona analiza regresji. Wynika z niej, że zależność tę można przedstawić w postaci funkcji:

$$
y=6,94+0,0006 x
$$

gdzie: $x$ - wydatki wewnętrzne na badania i rozwój; $y$ - środki pozyskiwane z programu Horyzont 2020 na badania związane z rozwojem rolnictwa i obszarów wiejskich. 
Współczynnik determinacji $\left(\mathrm{R}^{2}\right)$ dla powyższej zależności wynosi 0,49 i jest statystycznie istotny. W związku z powyższym można stwierdzić, że wzrost ogólnych nakładów wewnętrznych na B+R w krajach Unii Europejskiej o 1 mln euro prowadzi do wzrostu środków pozyskiwanych z programu Horyzont 2020 na badania związane z rolnictwem i rozwojem obszarów wiejskich o ok. 600 euro. Finansowanie przez dany kraj szeroko rozumianej działalności $\mathrm{B}+\mathrm{R}$ przynosi więc wymierne korzyści w postaci wzrostu zaangażowania zespołów naukowo-badawczych w badania międzynarodowe. Wzrost wydatków wewnętrznych na ten cel generuje dla gospodarki z jednej strony zwrot części poniesionych nakładów, a z drugiej zwiększenie zasobów wiedzy, do której gospodarka ta (lub określony jej sektor) ma dostęp. Zwiększenie transferu wiedzy do działalności gospodarczej, w tym sektora rolno-spożywczego, oraz poprawa innowacyjności wymagają istotnego wzrostu nakładów wewnętrznych na działalność $\mathrm{B}+\mathrm{R}$.

Na podstawie analizy struktury środków finansowych pozyskiwanych przez polskie instytucje naukowo-badawcze z programu Horyzont 2020 na projekty związane z rozwojem rolnictwa i obszarów wiejskich (rys. 2) można stwierdzić, że znaczna ich część przeznaczana jest na badania związane z wyzwaniami społecznymi, np. bezpieczeństwem żywnościowym czy zrównoważonym rolnictwem. Polskie instytucje podejmują również badania obejmujące ekologiczne aspekty produkcji rolnej, w tym odnoszące się do przeciwdziałania zanieczyszczeniu środowiska przyrodniczego przez ten sektor. W wielu obszarach, finansowanych z programu Horyzont 2020, występuje niestety całkowity brak zaangażowania. Przykładami są badania ukierunkowane na wzmocnienie zarządzania i innowacje społeczne na obszarach wiejskich, badania dotyczące różnorodności rolnictwa i łańcucha żywnościowego czy badania z zakresu bioekonomii. Polskie instytucje naukowo-badawcze nie realizują również projektów obejmujących współpracę z krajami pozaeuropejskimi. Skutkiem braku zaangażowania w określone obszary badań może być brak korzyści gospodarczych dla Polski. Ważnym zagadnieniem jest zatem identyfikacja przyczyn tego zjawiska i ich eliminowanie. Jak już wspomniano, jedną z barier może być zbyt niski poziom wydatków wewnętrznych. Niemniej można przyjąć, że wyjaśnia on to zjawisko jedynie połowicznie. Trzeba zatem założyć istnienie innych barier udziału polskich zespołów w projektach międzynarodowych. Ich przykładem może być często wskazywany przez sektor $\mathrm{B}+\mathrm{R}$ system oceny parametrycznej jednostek, nieadekwatny do poniesionych nakładów pracy.

Analizując finansowanie działalności $\mathrm{B}+\mathrm{R}$ na rzecz sektora rolno-spożywczego, trzeba jeszcze zwrócić uwagę na relacje pomiędzy udziałem tych wydatków w ogólnych wydatkach na rzecz sektora badawczo-rozwojowego a udziałem rolnictwa w PKB (rys. 3). Z danych Eurostatu wynika, że w ostatnich latach udział wydatków na nauki rolnicze jest na poziomie dwukrotnie wyższym niż udział wartości dodanej rolnictwa w PKB. Można więc przyjąć, że taki poziom finansowania powinien być akceptowalny dla instytucji naukowo-badawczych tego sektora. Biorąc jednak pod uwagę niski poziom ogólnych wydatków na $\mathrm{B}+\mathrm{R}$ oraz silniejszą tendencję spadkową 


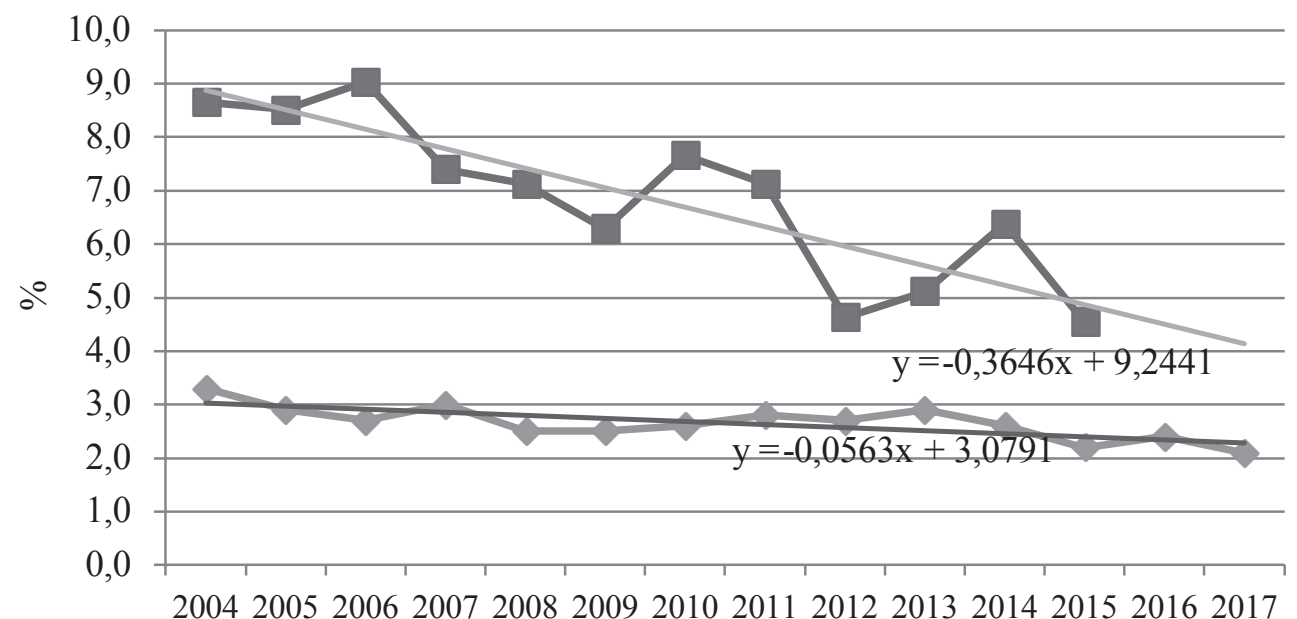

$\longrightarrow$ Udział wartości dodanej brutto rolnictwa, leśnictwa i rybactwa w PKB

UUdział wydatków wewnętrznych na nauki rolnicze w ogólnej kwocie wydatków wewnętrznych na działalność badawczo-rozwojową

— Liniowy (Udział wartości dodanej brutto rolnictwa, leśnictwa i rybactwa w PKB)

— Liniowy (Udział wydatków wewnętrznych na nauki rolnicze w ogólnej kwocie wydatków wewnętrznych na działalność badawczo-rozwojową)

Rys. 3. Wartość dodana brutto w rolnictwie, leśnictwie i rybactwie oraz wydatki wewnętrzne na nauki rolnicze w Polsce

Źródło: opracowanie własne na podstawie danych EUROSTAT.

udziału wydatków na nauki rolnicze (ok. 0,36 p.p. rocznie) niż w przypadku udziału rolnictwa w PKB (ok. 0,06 p.p. rocznie), należy stwierdzić, że transfer wiedzy i innowacji do tego sektora może być w najbliższych latach bardzo ograniczony. Brak innowacji i rosnące koszty pracy w sektorze mogą doprowadzi do istotnego spadku konkurencyjności produktów rolnych zarówno na rynku krajowym, jak i unijnym. To z kolei będzie barierą wdrażania koncepcji inteligentnego rozwoju.

\section{Zakończenie i wnioski}

Z badań wynika, że transfer nowej wiedzy do gospodarki przyczynia się do poprawy produktywności kapitału rzeczowego oraz wywołuje postęp techniczny. To podejście teoretyczne odnosi się do wszystkich sektorów gospodarki, w tym rolno-spożywczego. Tworzenie nowej wiedzy oraz innowacyjnych rozwiązań, a także ich transfer do sektora rolno-spożywczego wymaga znacznych nakładów finansowych. Zdecydowana większość wydatków na B+R jest w Polsce finansowana $\mathrm{z}$ budżetu 
państwa. Od wstąpienia Polski do Unii Europejskiej istnieje również możliwość wykorzystania $w$ tym celu programów unijnych. $Z$ analizy dystrybucji środków na badania w zakresie rolnictwa i rozwoju wsi wynika jednak, że zaangażowanie polskich instytucji jest niewielkie. Pozyskiwanie środków z tego źródła jest również uzależnione od ogólnego poziomu wydatków wewnętrznych. Udział wydatków na nauki rolnicze maleje także w odniesieniu do ogólnych wydatków na B+R. Konsekwencją obecnej skali finansowania działalności $\mathrm{B}+\mathrm{R}$ może być znaczne spowolnienie transferu nowej wiedzy i innowacji do sektora rolno-spożywczego i na obszary wiejskie, co z kolei może być barierą wdrażania koncepcji inteligentnego rozwoju wsi.

\section{Literatura}

Aghion P., Howitt P., 1992, Endogenous growth theory through creative destruction, Econometrica, no 60 .

Aghion P., Jarave X., 2015, Knowledge spillovers, innovation and growth, Economic Journal, 125 (March), John Wiley \& Sons Ltd., Malden, USA, s. 533-573.

Boeke J., 1953. Economics and economic policy in dual societies, New York University Press, New York.

Caballe J., Santos M., 1993, On endogenous growth with physical and human capital, Journal of Political Economy, vol. 101, no 6.

Caballero R., Jaffe A., 1993, How high are giants'shoulders: an empirical assessment of knowledge spillovers and creative destruction in a model of economic growth, NBER Macroeconomic Annual 1993, MIT Press, Cambridge.

Dworak E., Dybowski G., Nosecka B., 2016, Czynniki wzrostu gospodarczego i gospodarka oparta na wiedzy w rolnictwie, Monografie Programu Wieloletniego, nr 40, IERiGŻ-PIB, Warszawa, s. 122.

European Commission, 2017a, European Innovation Scoreboard, Brussels.

European Commission, 2017b, The Future of Food and Farming, Communication from the Commission to the European Parliament, the Council, the European Economic and Social Committee and the Committee of the Regions, COM (2017) 713 final, Brussels.

Firszt D., Jabłoński Ł., 2016, Kapitał ludzki i innowacje a zmniejszanie luki rozwojowej między kraja$m i, \mathrm{CeDeWu}$, Warszawa.

Galor O., Moav O., 2004, From physical to human capital accumulation: inequality and the process of development, Review of Economic Studies, vol. 71, no. 249, s. 1001-1026.

Hagen E., 1962, The theory of social change: how economic growth begins, Richard D. Irwin Inc., Homewood.

Kondonassis A., Malliaris A., Okediji T., 2000, Swing of the pendulum: a review of theory and practice in development economics, American Economist, vol. 44, no. 1.

McClelland D., 1962, The achieving society, Princeton University Press, Princeton.

North D., 2005, Institutions and the performance of economies over time, [w:] C. Menard, M.M. Shirley, Handbook of New Institutional Economics, Springer, Dordrecht-Berlin-Heidelberg-New York, s. 22-23.

Prystrom J., Wierzbicka K., 2015, Finansowanie działalności innowacyjnej, Difin, Warszawa.

Romer P., 1990, Engogenous technological change, Journal of Political Economy, vol. 94, s. 71-102.

Schultz T., 1962, Reflections on investment in man, Journal of Political Economy, vol. 70, s. 1-8. 
Szczepaniak I. (red.), 2017, Konkurencyjność polskich producentów żywności i jej determinanty (3), Monografie Programu Wieloletniego, nr 67, IERiGŻ-PIB, Warszawa, s. 214.

Wasilewska A., Wasilewski M., 2016, Stan, kierunki i efektywność innowacji w przedsiębiorstwach przetwórstwa rolno-spożywczego, SGGW, Warszawa, s. 332.

Wasilewski A., 2016, Przestanki i uwarunkowania instytucjonalnego wsparcia transferu innowacji do sektora przetwórstwa spożywczego, Problemy Ekonomii, Polityki Ekonomicznej i Finansów Publicznych, Prace Naukowe nr 439, Uniwersytet Ekonomiczny we Wrocławiu, Wrocław.

Wigier M. (red.), 2014, Wsparcie publiczne i konkurencyjność polskiej gospodarki żywnościowej, Monografie Programu Wieloletniego, nr 129, IERiGŻ-PIB, Warszawa, s. 136. 